\title{
A SsrA/Nla-based Strategy for Post-Translational Regulation of Protein Levels in Gram-negative Bacteria
}

Gonzalo Durante-Rodríguez ${ }^{1, *}$, Belén Calles², Víctor de Lorenzo ${ }^{2}$ and Pablo I. Nikel ${ }^{3}$

${ }^{1}$ Environmental Microbiology Group, Centro de Investigaciones Biológicas (CIB-CSIC), 28040 Madrid, Spain; ${ }^{2}$ Systems and Synthetic Biology Department, Centro Nacional de Biotecnología (CNB-CSIC), 28049 Madrid, Spain; ${ }^{3}$ Systems Environmental Microbiology Group, The Novo Nordisk Foundation Center for Biosustainability, Technical University of Denmark, 2800 Kgs Lyngby, Denmark

*For correspondence: gdurante@cib.csic.es

[Abstract] Strategies to control the levels of key enzymes of bacterial metabolism are commonly based on the manipulation of gene of interest within the target pathway. The development of new protocols towards the manipulation of biochemical processes is still a major challenge in the field of metabolic engineering. On this background, the FENIX (functional engineering of SsrA/Nla-based flux control) system allows for the post-translational regulation of protein levels, providing both independent control of the steady-state protein amounts and inducible accumulation of target proteins. This strategy enables an extra layer of control over metabolic fluxes in bacterial cell factories (see Graphical abstract below). The protocol detailed here describes the steps needed to design FENIX-tagged proteins and to adapt the system to virtually any pathway for fine-tuning of metabolic fluxes.

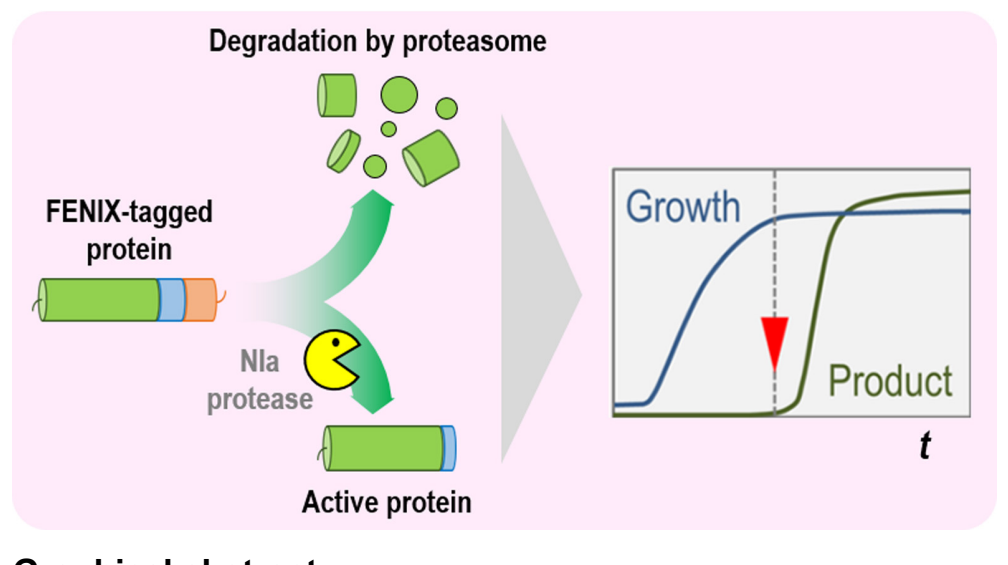

\section{Graphical abstract}

Keywords: Synthetic biology, Metabolic engineering, Proteolysis, Escherichia coli, Pathway engineering

[Background] Controlling protein production has become a challenging problem that has been mostly tackled by manipulating the regulation of its production at different levels, such as the DNA level or the amount of protein(s) produced (Wu et al., 2016; Avcilar-Kucukgoze et al., 2017). At the DNA level, both transcription and translation have been widely studied in several microorganisms, enabling the design 
and development of a large number of synthetic circuits to improve bioproduction processes (Guzmán et al., 1995; Lutz and Bujard, 1997). In contrast, the protein level has been much less studied, with protocols mainly based on RNA interference, riboregulators and specific transcriptional regulators (Isaacs et al., 2004; Lou et al., 2012).

In order to implement a new approach towards the regulation of protein levels, we recently proposed a synthetic biology tool called FENIX (functional engineering of SsrA/Nla-based flux control) (DuranteRodríguez et al., 2018). FENIX is based on the activity of the protease Nla, capable of recognizing and cleaving a specific sequence of 13 amino acids (the nia target, GESNVVVHQADER) (Verchot et al., 1991; Stevens, 2000; Calles et al., 2019), and the action of the proteasome, which recognizes a sequence of 11 amino acids located in the C-terminal region of a protein (the ssrA target, AANDENYALAA) (Doma and Parker, 2007; Shoemaker et al., 2010). We have designed a synthetic $\mathrm{Nla/SsrA} \mathrm{tag}$ (GESNVVVHQADER•AANDENYALAA) that can be easily fused to the C-terminal module of any protein of interest via a single cloning step in a standardized vector. The FENIX system relies on the constitutive degradation of the target protein by the proteasome, followed by conditionally restoring protein accumulation by the cleavage of the proteasome tag $(s s / A)$ through the action of the protease $\mathrm{Nla}$. The whole circuit is triggered by the addition of 3-methylbenzoate, which induces the XyIS/Pm expression system, thus controlling the individual components of the FENIX system. This novel tool can be also used in Pseudomonas putida for tight control of protein accumulation (Volke et al., 2020). The protocol described below discusses the overall strategy along with specific details on its implementation.

\section{Materials and Reagents}

A. Kits

1. High-Pure plasmid isolation kit (Roche, catalog number: 11754777001)

2. Gene-Clean Turbo kit (Q-BIOgene, catalog number: 1102-400)

B. Enzymes

1. Pfu DNA polymerase (Promega, catalog number: M7741)

2. T4 DNA ligase (New England Biolabs, catalog number: M0202L)

3. Restriction enzyme Nhel (New England Biolabs, catalog number: R3131S)

4. Restriction enzyme BsrGI (New England Biolabs, catalog number: R3575S)

5. Restriction enzyme Spel (New England Biolabs, catalog number: R3133L)

C. Chemicals and other consumables

1. $0.22 \mu \mathrm{m}$ filter membranes (Merck, catalog number: GSWP02500)

2. Multiwell microtiter plates, 96-well, Flat Bottom (Falcon, catalog number: 353072)

3. $50 \mathrm{ml}$ plastic tubes (Falcon)

4. 2-ml microcentrifuge tubes

5. $1.5-\mathrm{ml}$ microcentrifuge tubes 
6. Aluminum foil

7. Petri dishes

8. Chloramphenicol (Sigma-Aldrich, catalog number: C0378-25G)

9. Kanamycin sulfate (Roche, catalog number: 10106801001)

10. Absolute ethanol (Sigma-Aldrich, catalog number: 1009832500)

11. $85 \%(\mathrm{v} / \mathrm{v})$ glycerol (Sigma-Aldrich, catalog number: 1040942500)

12. $\mathrm{NaCl}$ (Merck, catalog number: 1.06404.1000)

13. $\mathrm{NaOH}$ (Merck, catalog number: 1.06498 .0500 )

14. $\mathrm{CaCl}_{2}$ (Merck, catalog number: 1.02382 .1000 )

15. $\mathrm{RbCl}$ (Sigma-Aldrich, catalog number: R2252-100G)

16. $\mathrm{MnCl}_{2}$ (Merck, catalog number: 1.05927 .0100 )

17. Potassium acetate (Merck, catalog number: 1.04820.1000)

18. Acetic acid (glacial) (Merck, catalog number: 1.00063.1000)

19. MOPS (Sigma-Aldrich, catalog number: M1254-250G)

20. 3-methylbenzoate (Sigma-Aldrich, catalog number: 89890)

21. Agar (Conda, catalog number: 1806)

22. Agarose D1 (Conda, catalog number: 8019.22)

23. Bacto ${ }^{\mathrm{TM}}$ tryptone (BD, catalog number: 211705$)$

24. Bacto ${ }^{\mathrm{TM}}$ yeast (BD, catalog number: 212750$)$

25. Competent $E$. coli $\mathrm{DH} 10 \mathrm{~B}$ cells (see Recipes)

26. Solution for DH10B competent cells TBFI (see Recipes)

27. Solution for DH10B competent cells TBFII (see Recipes)

28. $30 \mathrm{mg} / \mathrm{ml}$ chloramphenicol and $50 \mathrm{mg} / \mathrm{ml}$ kanamycin (see Recipes)

29. LB broth (see Recipes)

30. LB agar with $30 \mu \mathrm{g} / \mathrm{ml}$ chloramphenicol and/or $50 \mu \mathrm{g} / \mathrm{ml}$ kanamycin (see Recipes)

31. 0.5 M 3-methylbenzoate (see Recipes)

32. $50 \%(\mathrm{v} / \mathrm{v})$ and $70 \%(\mathrm{v} / \mathrm{v})$ ethanol (see Recipes)

\section{Equipment}

1. ABI Prism 377 automated DNA sequencer (Applied Biosystems Inc.)

2. Electroporator (Gene Pulser, Bio-Rad)

3. Orbital shaker

4. Flasks $(50 \mathrm{ml}, 1 \mathrm{~L})$

5. Pipettes (Gilson, models: PIPETMAN P2, P10, P20, P100, P200, P1000, P5000)

6. Centrifuge (Tomy, model: MX-301)

7. Thermal Cycler (Applied Biosystems, model: 2720Thermal Cycler)

8. Temperature chamber (Taitec, model: Thermo minder SM-10R)

9. Water bath shaker (Taitec, model: Personal-11) 
10. Plate reader (Corona, model: MTP-880Lab)

11. Autoclave (Tomy Seiko, model: LSX-500)

\section{Software}

1. Microsoft Excel (Microsoft)

2. BioEdit Sequence Alignment Editor

3. ApE-A plasmid Editor (https://jorgensen.biology.utah.edu/wayned/ape)

\section{Procedure}

The design and construction of a target gene tagged according to the FENIX system could be divided into the following 4 steps (A to $D$ ), summarized in Figure 1.

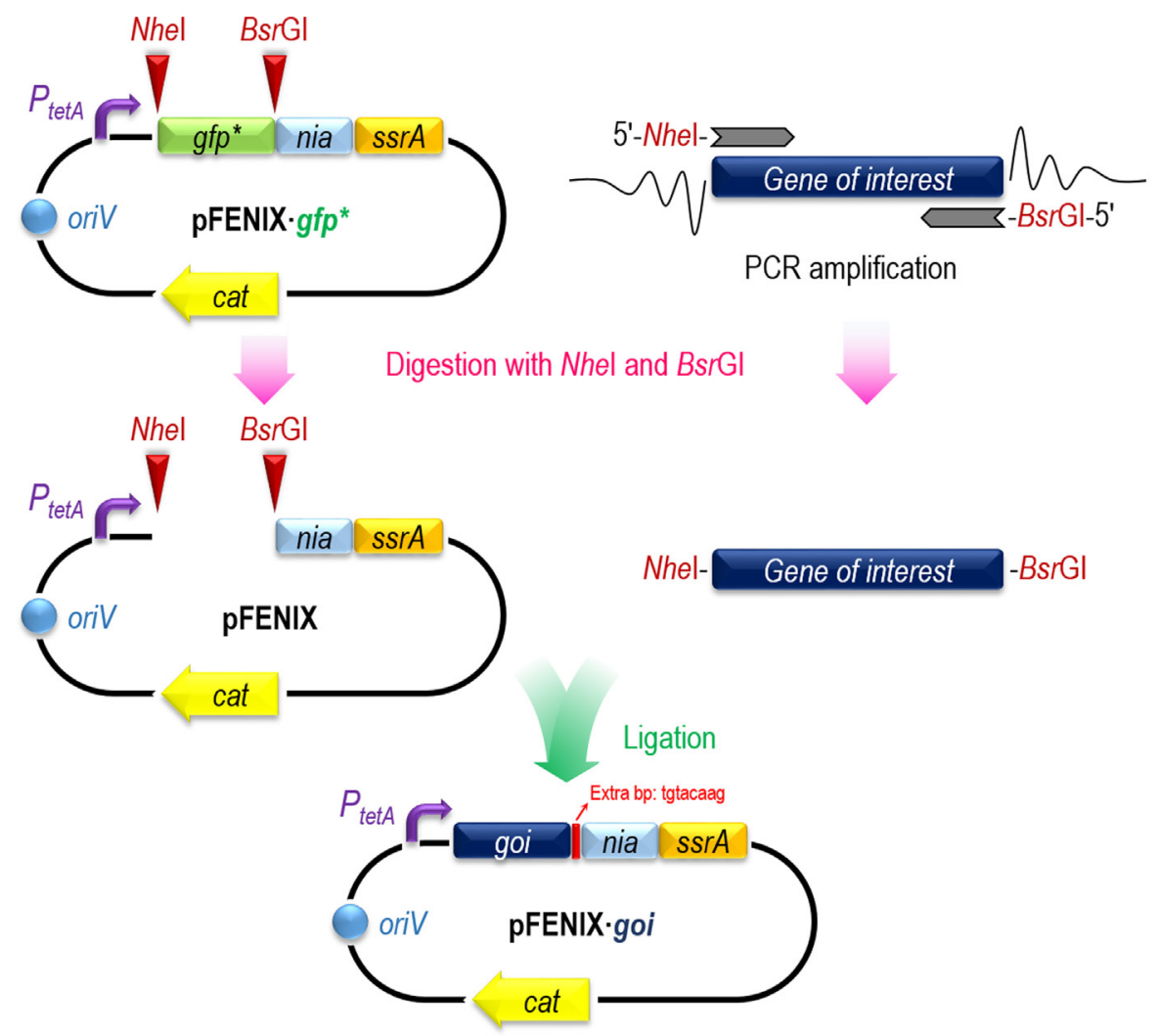

Figure 1. Rationale and construction of the FENIX system for one-step cloning and tagging of individual target proteins. The gene encoding the target polypeptide (gene of interest, goi) is amplified by PCR with specific oligonucleotides that include Nhel and BsrGI restriction sites. The resulting amplicon can be directly cloned into plasmid pFENIX·gfp* (which contains a nia/ssrA tagged version of the green fluorescent protein, see Table 1 and Supplementary file) upon digestion with these two restriction enzymes. The Nhel restriction site is located between the RBS and the ATG of gfp gene so the N-terminal region of goi will keep without any modification, and the C- 
terminal region will contain eight extra bp (in red) between goi and nia sequences, translated as $\mathrm{XYK}$ amino acids ( $\mathrm{X}$ could be L, M or $\mathrm{V}$ amino acid depending on the last bp of the goi). After ligation, the new plasmid pFENIX·goi is transformed into competent $E$. coli DH10B cells. In all pFENIX plasmids, the expression of the nia/ssrA-tagged variant of the goi depends on the constitutive $P_{\text {tetA }}$ promoter.

Table 1. Bacterial strains and plasmids

\begin{tabular}{|c|c|c|}
\hline $\begin{array}{l}\text { Strain or } \\
\text { plasmid }\end{array}$ & Description & Reference \\
\hline \multicolumn{3}{|c|}{ Escherichia coli } \\
\hline DH10B & $\begin{array}{l}\text { Cloning host; } \mathrm{F}^{-} \lambda^{-} \text {endA1 recA1 galK galU } \Delta(\text { ara-leu }) 7697 \text { araD139 } \\
\text { deoR nupG rpsL } \Phi 80(\text { lacZAM15) mcrA } \Delta(\text { mrr-hsdRMS-mcrBC) } \\
\Delta l a c X 74\end{array}$ & Durfee et al. (2008) \\
\hline \multicolumn{3}{|l|}{ Plasmids } \\
\hline pSEVA238 & Expression vector; oriV(pBBR1), XyIS/Pm expression system; $K m^{R}$ & $\begin{array}{l}\text { Silva-Rocha et al. } \\
(2013)\end{array}$ \\
\hline $\mathrm{pS} 238 \cdot \mathrm{Nla}$ & $\begin{array}{l}\text { Derivative of vector pSEVA238 used for regulated expression of nia, } \\
\text { encoding the potyvirus Nla protease; XyIS/Pm } \rightarrow \text { nia; } K m^{R}\end{array}$ & $\begin{array}{l}\text { Durante-Rodríguez } \\
\text { et al. (2018) }\end{array}$ \\
\hline $\mathrm{pS} 341 \mathrm{~T} \cdot g f p$ & $\begin{array}{l}\text { Derivative of vector pSEVA341T used for constitutive expression of } \\
g f p ; \mathrm{P}_{\text {tetA }} \rightarrow g f p ; \mathrm{Cm}^{R}\end{array}$ & $\begin{array}{l}\text { Durante-Rodríguez } \\
\text { et al. (2018) }\end{array}$ \\
\hline $\mathrm{pS} 341 \mathrm{~T} \cdot g f p^{*}$ & $\begin{array}{l}\text { Derivative of vector pSEVA341T used for constitutive expression of } \\
\text { a variant of } g f p\left(g f p^{*}\right) ; P_{\text {tetA }} \rightarrow g f p^{*} ; \mathrm{Cm}^{R}\end{array}$ & $\begin{array}{l}\text { Durante-Rodríguez } \\
\text { et al. (2018) }\end{array}$ \\
\hline pFENIX·gfp* & $\begin{array}{l}\text { Derivative of plasmid } p S 341 \mathrm{~T} \cdot g f p^{*} \text { in which } g f p \text { has been tagged } \\
\text { with nia and } s s r A \text { recognition targets; } \mathrm{Cm}^{R}\end{array}$ & $\begin{array}{l}\text { Durante-Rodríguez } \\
\text { et al. (2018) }\end{array}$ \\
\hline
\end{tabular}

A. Construction of pFENIX plasmids for one-step cloning and tagging of individual target proteins

1. Select the gene encoding the target polypeptide (gene of interest, goi).

2. Design specific oligonucleotides to amplify the goi, including Nhel (5'-GCTAGC-3') and BsrGI (5'-TGTACA-3') restriction sites in the $5^{\prime}$ and $3^{\prime}$ termini, respectively.

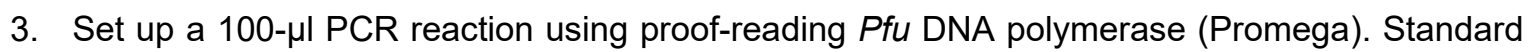
reaction conditions can be used as described in the provider manual's for Pfu DNA polymerase. In most cases, thermal cycling conditions are as follows: after heating at $98^{\circ} \mathrm{C}$ for $5 \mathrm{~min}$, set 30 cycles of $98^{\circ} \mathrm{C}$ for $30 \mathrm{~s}$ (denaturation), $57^{\circ} \mathrm{C}$ for $30 \mathrm{~s}$ (annealing, temperature varies depending on the actual $\mathrm{Tm}$ of the oligonucleotides used), and $72{ }^{\circ} \mathrm{C}$ for $1 \mathrm{~min}$ (elongation, time varies depending on the size of the goi to be amplified, typically $2 \mathrm{~min} / \mathrm{kb}$ ).

4. Purify the PCR product by using the Gene-Clean Turbo kit (Q-BIOgene).

Note: When the PCR amplification yields non-specific bands, the target product is cut from an agarose gel after electrophoresis by loading the total volume of PCR and the amplicon is gelpurified by means of the Gene-Clean Turbo kit. 
5. Digest plasmid pFENIX and the PCR product of the goi with the restriction enzymes Nhel and $B s r G I$, and then purify both DNA fragments using the Gene-Clean Turbo kit.

6. Clone the goi in the pFENIX backbone by the T4 DNA ligase (New England Biolabs), adding a goi concentration 5-10 times higher than the plasmid pFENIX in a final volume of $20 \mu$.

B. Cell transformation with the pFENIX-goi plasmid

1. Keep competent $E$. coli $\mathrm{DH} 10 \mathrm{~B}$ cells on ice. This protocol has been carried out with strain DH10B taking into account its high competence skills, but any E. coli strain routinely used for cloning (e.g., DH5a) could be likewise used.

2. Take the $20-\mu l$ ligation mixture from the step before and add it into $0.1 \mathrm{ml}$ of the cell suspension of competent $E$. coli $\mathrm{DH} 10 \mathrm{~B}$ (see Recipes), and then incubate the mixture on ice for $30 \mathrm{~min}$.

3. Heat-shock the cells at $42{ }^{\circ} \mathrm{C}$ for $45 \mathrm{~s}$, and immediately add $0.9 \mathrm{ml}$ of $\mathrm{LB}$ broth to the mixture.

4. Incubate $1 \mathrm{ml}$ of the suspension of $E$. coli DH10B transformants at $37^{\circ} \mathrm{C}$ for $60 \mathrm{~min}$.

5. Spread $0.1 \mathrm{ml}$ and/or the rest of the suspension of $E$. coli DH10B transformants onto LB agar plates with $30 \mu \mathrm{g} / \mathrm{ml}$ chloramphenicol, and then incubate the plates at $37^{\circ} \mathrm{C}$ overnight.

6. Isolate a transformant of E. coli $\mathrm{DH} 10 \mathrm{~B}$ harboring the cloned candidates on the LB agar with $30 \mu \mathrm{g} / \mathrm{ml}$ chloramphenicol.

7. Inoculate a single colony into $10 \mathrm{ml}$ of LB broth containing $30 \mu \mathrm{g} / \mathrm{ml}$ chloramphenicol in a $50-\mathrm{ml}$ conical tube, and incubate the culture in an orbital shaker at $37^{\circ} \mathrm{C}$ with shaking (180 rpm) overnight.

8. Isolate the plasmid from the transformant cells of $10 \mathrm{ml}$ overnight culture by means of the HighPure plasmid isolation kit (Roche).

9. Check the DNA sequence of the tagged goi cloned into the pFENIX plasmid with an ABI Prism 377 automated DNA sequencer (Applied Biosystems Inc.), using the universal primers R24 (5'AGCGGATAACAATTTCACACAGGA-3') and F24 (5'-CGCCAGGGTTTTCCCAGTCACGAC-3').

10. Compare the sequence of the clones with that of the reference sequence to ensure the absence of mutations. An alignment software such as Bioedit or ApE-A could be used.

11. Long-term storage of bacterial strains transformed with these plasmids is routinely done as $15 \%$ glycerol stocks according to well-established procedures (Sambrook and Russell, 2001).

C. Electroporation of pFENIX recombinants with the plasmid encoding the Nla protease

1. Incubate a $20-\mathrm{ml}$ culture of $E$. coli $\mathrm{DH} 10 \mathrm{~B}$ harboring plasmid pFENIX'goi in LB medium overnight at $37^{\circ} \mathrm{C}$ with shaking (180 rpm) in an orbital shaker.

2. Distribute the whole culture in a $50-\mathrm{ml}$ sterile conical tube and centrifuge at $2,300 \times \mathrm{g}$ and $4^{\circ} \mathrm{C}$ for $10 \mathrm{~min}$.

3. Remove supernatant, resuspend the pellet gently in $10-\mathrm{ml}$ of cold sterile water $\left(4^{\circ} \mathrm{C}\right)$ and centrifuge at $2,300 \times g$ and $4{ }^{\circ} \mathrm{C}$ for $10 \mathrm{~min}$.

4. Discard supernatant, add $1 \mathrm{ml}$ of sterile cold water, resuspend the pellet and transfer the suspension to a $2-\mathrm{ml}$ microcentrifuge tube. 
5. Centrifuge at $3,800 \times g$ and $4{ }^{\circ} \mathrm{C}$ for 5 min. Repeat this step 2 times.

Note: The cells are ready to be electroporated when they form a very soft and loose pellet after the centrifugation with cold water.

6. Dispose of the supernatant and add $300 \mu \mathrm{l}$ of cold sterile water, resuspend and distribute $100 \mu \mathrm{l}$ of the resulting suspension into 2-mm gap width electroporation cuvettes.

7. Add $200 \mathrm{ng}$ of the plasmid pS238. Nla to the electroporation cuvette containing $100 \mu \mathrm{l}$ of the suspension of E. coli $\mathrm{DH} 10 \mathrm{~B}$ cells harboring the plasmid pFENIX·goi, mix gently and proceed to electroporate in an electroporator (Gene Pulser, Bio-Rad).

Note: The parameters of electroporation are resistance, $200 \Omega$; capacitance, $25 \mu \mathrm{F}$; and voltage, $2.5 \mathrm{kV}$.

8. Add $0.9 \mathrm{ml}$ of LB medium to the cell suspension and incubate for $1 \mathrm{~h}$ at $37^{\circ} \mathrm{C}$ with shaking (180 rpm) in an orbital shaker.

9. Plate the whole culture onto LB medium plates added with $30 \mu \mathrm{g} / \mathrm{ml}$ chloramphenicol and $50 \mu \mathrm{g} / \mathrm{ml}$ kanamycin.

10. Streak a few colonies and check for the presence of both plasmid pFENIX·goi and pS238-Nla in the transformant bacteria by plasmid extraction (High-Pure plasmid isolation kit, Roche).

11. Digest the mixture of both plasmids extracted with Spel (5'-ACTAGT-3') and run an agarose gel electrophoresis to check the relevant sizes. Expect a band of approximately $3.6 \mathrm{~kb}$ plus the size of the corresponding goi with pFENIX·goi, and a band of approximately $5.8 \mathrm{~kb}$ of the empty pS238. Nla vector.

D. Protocol for activation of the protease Nla in the FENIX native system with GFP* (Figure 2)

1. Select a single colony of the E. coli transformants harbouring the plasmids listed below (Table 1):

pS238-Nla (negative control)

pS341T.gfp (positive control)

pSEVA238 and pFENIX $g f p^{*}$ (control strain without the protease Nla)

pS238.Nla and pFENIX·gfp*

2. Individually inoculate the four recombinant strains in 50-ml conical tubes with $10 \mathrm{ml}$ of LB medium containing $30 \mu \mathrm{g} / \mathrm{ml}$ chloramphenicol (for the positive control), $50 \mu \mathrm{g} / \mathrm{ml}$ kanamycin (for the negative control), or both antibiotics (for strains containing both plasmids).

3. Incubate the pre-culture overnight at $37^{\circ} \mathrm{C}$ with shaking (180 rpm).

4. Inoculate $4 \mu$ l of each overnight pre-culture in a 96 -well microtiter plate containing $200 \mu$ l of fresh LB medium per well, including $30 \mu \mathrm{g} / \mathrm{ml}$ chloramphenicol and $/ o r 50 \mu \mathrm{g} / \mathrm{ml}$ kanamycin, and in presence or absence of $1 \mathrm{mM} 3$-methylbenzoate as the inducer of nia expression (in the case of strains harbouring the pFENIX·gfp* plasmid). Each experiment should be carried out in three independent wells as technical replicates.

5. Incubate the 96 -well microtiter plate at $37^{\circ} \mathrm{C}$ with shaking in a plate reader during $24 \mathrm{~h}$, till the stationary phase. 
6. Measure the $\mathrm{OD}_{600}$ and the GFP fluorescence in the plate reader at the endpoint of the growth curve (Figure 2). GFP is excited at $488 \mathrm{~nm}$, the fluorescence signal is recovered at $511 \mathrm{~nm}$, and it was used the bottom reading mode.

A

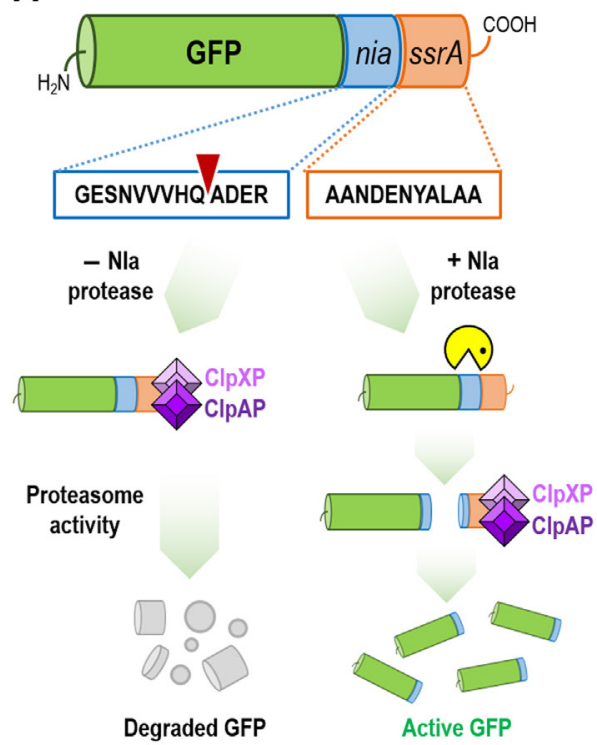

B

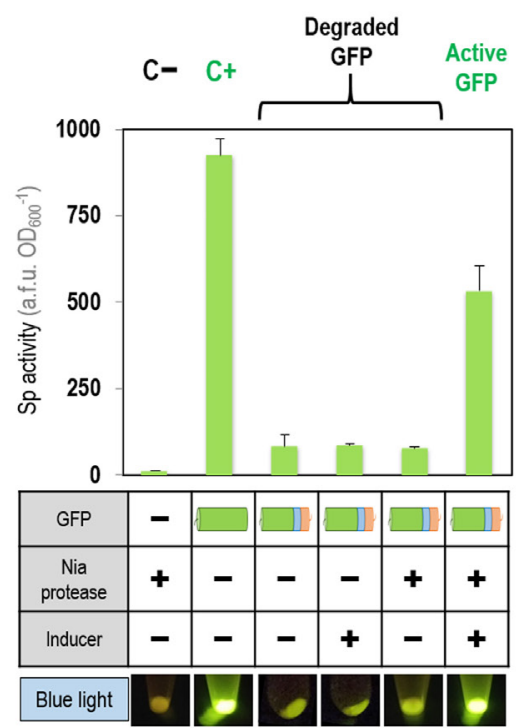

Figure 2. Performance of the FENIX system with GFP fluorescence as the readout. A. Scheme of Nla and SsrA-dependent post-translational control of GFP with the FENIX system. The gene encoding the green fluorescence protein (GFP) is added with a synthetic, hybrid nia/ssrA tag, resulting in a tagged GFP variant in which the C-terminus displays the GESNVVVHQADER-AANDENYALAA amino acid sequence. The SsrA tag is directly recognized by the CIpXP and ClpAP proteases of the bacterial proteasome in vivo, thus degrading the protein. Upon action of the specific potyvirus Nla protease (the recognition site in the synthetic nia/ssrA tag is indicated with an inverted red triangle in the diagram), the SsrA tag is released and GFP can be accumulated, resulting in the appearance of $\mathrm{GFP}^{+}$cells. B. Evaluation of the FENIX system in recombinant $E$. coli using GFP protein. Plasmid pFENIX·gfp ${ }^{*}$, which contain the nia/ssrA-tagged version of GFP (indicated with blue and orange strips in the first row of the table), were transformed into E. coli DH10B carrying either plasmid pS238. Nla or the empty pSEVA238 vector (indicated as + and -, respectively, in the second row of the table). The first two columns represent a negative and positive control, respectively, carried out with E. coli DH10B transformed either with the empty pFENIX vector (i.e., no GFP protein) or with a plasmid constitutively expressing the gene encoding $g f p^{*}\left(p S 341 \mathrm{~T} \cdot g f p^{*}\right.$, Table 1). Strains indicated in the next four columns contain the nia/ssrA-tagged GFP. These experiments were done in 96-well microtiter plates containing LB medium with the necessary antibiotics and additives (1 mM 3-methylbenzoate as the inducer of nia expression, as indicated in the third row of the table), and were inoculated with a culture of the corresponding strain previously grown in LB medium with the necessary antibiotics overnight. Cells were incubated at $37^{\circ} \mathrm{C}$ with rotary agitation, and fluorescence and bacterial growth (expressed as the optical 
density measured at $\left.600 \mathrm{~nm}, \mathrm{OD}_{600}\right)$ were recorded after $24 \mathrm{~h}$. The specific (Sp) activity of the fluorescent proteins under study was calculated as the arbitrary fluorescence units (a.f.u.) normalized to the $\mathrm{OD}_{600}$. Each bar represents the mean value of the $\mathrm{Sp}$ activity \pm standard deviation calculated from at least three independent experiments. The lower panel shows bacterial pellets harvested from shake-flask cultures after $24 \mathrm{~h}$ of incubation under the same growth conditions indicated for the microtiter-plate cultures as observed under blue light.

\section{Data analysis}

1. Extract raw numeric data of both $\mathrm{OD}_{600}$ values and the measurement of GFP fluorescence in absence or presence of the inducer as a text file.

2. Open a text file containing the raw numeric data in a software for data management such as Microsoft Excel, R or Sigma Plot.

3. Normalize the values of $\mathrm{OD}_{600}$ and the net intensities of the GFP fluorescence.

4. Calculate the ratio of fluorescence to $\mathrm{OD}_{600}$ as specific activity of the promoter of each culture by the following formula:

$$
S p=I F / O D_{600}
$$

$\mathrm{Sp}$ is the specific activity

IF is the intensity of fluorescence in arbitrary units

$\mathrm{OD}_{600}$ is the cell concentration in units of optical density

5. Average the ratios from three independent experiments with the technical replicates that are used to calculate the mean specific activity along with the deviations typical corresponding.

6. To confirm a significant difference, calculated $P$-values by Student's $t$-test (one-tailed and unpaired) of statistical analysis should be evaluated at less than 0.01 (Durante-Rodríguez et al., 2018).

\section{$\underline{\text { Recipes }}$}

1. Competent E. coli $\mathrm{DH} 10 \mathrm{~B}$ cells

a. Inoculate a single colony of E. coli DH10B in $10 \mathrm{ml}$ of LB broth in a 50-ml Erlenmeyer flask

b. Incubate the pre-cultures overnight at $37^{\circ} \mathrm{C}$ with shaking (180 rpm)

c. Dilute the pre-culture 100 -fold in $250 \mathrm{ml}$ of fresh LB broth in a 1-L Erlenmeyer flask

d. Incubate the cultures at $37^{\circ} \mathrm{C}$ with shaking $(180 \mathrm{rpm})$ until mid-exponential phase (optical density measured at $600 \mathrm{~nm} \sim 0.5-0.6$ )

e. Keep the cell suspension in an ice batch for $30 \mathrm{~min}$

f. Distribute the $250 \mathrm{ml}$ of culture to sterile $50-\mathrm{ml}$ conical tubes 
g. Collect the cells by centrifugation $\left(2,300 \times \mathrm{g}, 4^{\circ} \mathrm{C}, 5 \mathrm{~min}\right)$ and combine the pellets in a single tube

h. Suspend the cells in $30 \mathrm{ml}$ of TBFI (see Recipe 2) per $100 \mathrm{ml}$ of original cell suspension

i. Incubate the cells in an ice bath for $2 \mathrm{~h}$

j. Collect the cells by centrifugation $\left(2,300 \times g, 4{ }^{\circ} \mathrm{C}, 5 \mathrm{~min}\right)$

k. Suspend the cells in $4 \mathrm{ml}$ of TBFIl (see Recipe 3) per $100 \mathrm{ml}$ of cells

I. Transfer the suspension to pre-chilled 1.5- $\mathrm{ml}$ microcentrifuge tubes in aliquots of $100 \mu \mathrm{l}$

$\mathrm{m}$. Use an aliquot $(\sim 100 \mu \mathrm{l})$ of the resuspended E. coli DH10B for transformation

2. Solution for $\mathrm{DH} 10 \mathrm{~B}$ competent cells TBFI

a. To prepare $250 \mathrm{ml}$ of final volume of TBFI, dissolve $0.74 \mathrm{~g}$ of potassium acetate, $0.37 \mathrm{~g}$ of $\mathrm{CaCl}_{2}$ and $43.1 \mathrm{ml}$ of $85 \%(\mathrm{v} / \mathrm{v})$ glycerol in distilled water

b. Adjust the $\mathrm{pH}$ to 6.0 by dropwise addition of $0.2 \mathrm{M}$ acetic acid

c. Add $2.47 \mathrm{~g}$ of $\mathrm{MnCl}_{2}$ and $3.02 \mathrm{~g}$ of $\mathrm{RbCl}$, checking that the $\mathrm{pH}$ value stay at 5.8 (if not, readjust by dropwise addition of $0.2 \mathrm{M}$ acetic acid)

d. Sterilize the solution by filtration with a $0.22-\mu \mathrm{m}$ filter membrane (Merck)

e. Store the sterilized solution at $4{ }^{\circ} \mathrm{C}$ wrapped in aluminum foil

3. Solution for $\mathrm{DH} 10 \mathrm{~B}$ competent cells TBFII

a. To prepare $250 \mathrm{ml}$ of final volume of TBFII, dissolve $2.75 \mathrm{~g}$ of $\mathrm{CaCl}_{2}, 0.3 \mathrm{~g}$ of RbCl, $0.52 \mathrm{~g}$ of MOPS and $43.1 \mathrm{ml}$ of $85 \%(\mathrm{v} / \mathrm{v})$ glycerol in distilled water

b. Adjust the $\mathrm{pH}$ to 6.8 by dropwise addition of $10 \mathrm{~N} \mathrm{NaOH}$

c. Sterilize the solution by filtration with $0.22-\mu \mathrm{m}$ filter membrane (Merck)

d. Store the sterilized solution at $4{ }^{\circ} \mathrm{C}$ wrapped in aluminum foil

4. $30 \mathrm{mg} / \mathrm{ml}$ chloramphenicol and $50 \mathrm{mg} / \mathrm{ml}$ kanamycin

a. Dissolve $0.3 \mathrm{~g}$ of chloramphenicol (Sigma) and $0.5 \mathrm{~g}$ of kanamycin sulfate (Sigma) in $10 \mathrm{ml}$ of $70 \%(\mathrm{v} / \mathrm{v})$ ethanol or distilled water, respectively

b. Sterilize the solutions by filtration with $0.22-\mu \mathrm{m}$ filter membrane (Merck)

c. Store the sterilized solutions at $-20^{\circ} \mathrm{C}$

5. LB broth

a. Dissolve $10 \mathrm{~g}$ of Bacto ${ }^{\mathrm{TM}}$ tryptone, $5 \mathrm{~g}$ of Bacto $^{\mathrm{TM}}$ yeast extract, and $10 \mathrm{~g}$ of NaCl in $800 \mathrm{ml}$ of distilled water

b. Adjust $\mathrm{pH}$ to 7.5 with $10 \mathrm{~N} \mathrm{NaOH}$

c. Adjust volume to $1 \mathrm{~L}$ with distilled water

d. Autoclave the solution (set at $121^{\circ} \mathrm{C}$ and $20 \mathrm{~min}$ in an LSX-500 autoclave)

e. Store the sterile LB broth at room temperature

6. LB agar with $30 \mu \mathrm{g} / \mathrm{ml}$ chloramphenicol and/or $50 \mu \mathrm{g} / \mathrm{ml}$ kanamycin

a. Dissolve $7.5 \mathrm{~g}$ of agar in $1 \mathrm{~L}$ of LB broth

b. Autoclave (set $121^{\circ} \mathrm{C}$ and $20 \mathrm{~min}$ in LSX-500)

c. Add chloramphenicol and/or kanamycin after cooling in the final concentration of $30 \mu \mathrm{g} / \mathrm{ml}$ and $50 \mu \mathrm{g} / \mathrm{ml}$, respectively 
d. Pour the media into Petri dishes, and then let the LB agar solidify by cooling at room temperature

e. Store the LB agar plates upside down at $4{ }^{\circ} \mathrm{C}$

7. $0.5 \mathrm{M}$ 3-methylbenzoate

a. Dissolve $6.75 \mathrm{~g}$ 3-methylbenzoate (Sigma) in $100 \mathrm{ml}$ of $50 \%(\mathrm{v} / \mathrm{v})$ ethanol

b. Sterilize the solution by filtration with $0.22-\mu \mathrm{m}$ filter membrane (Merck)

C. Store the solution at $4{ }^{\circ} \mathrm{C}$

8. $50 \%(\mathrm{v} / \mathrm{v})$ and $70 \%(\mathrm{v} / \mathrm{v})$ ethanol

a. Dilute ethanol to $50 \%(\mathrm{v} / \mathrm{v})$ or $70 \%(\mathrm{v} / \mathrm{v})$ with sterile water

b. Store at room temperature

\section{Acknowledgments}

Financial support from The Novo Nordisk Foundation (NNF10CC1016517 and NNF 18CC0033664), the Danish Council for Independent Research (SWEET, DFF-Research Project 8021-00039B), and the European Union's Horizon2020 Research and Innovation Program under grant agreement No. 814418 (SinFonia) to P.I.N. is gratefully recognized. This work was funded also by the MADONNA (H2020-FET-OPEN-RIA-2017-1-766975), BioRoboost (H2020-NMBP-BIO-CSA-2018), SYNBIO4FLAV (H2020-NMBP/0500) and MIX-UP (H2020-Grant 870294) Contracts of the European Union and the S2017/BMD-3691 InGEMICS-CM Project of the Comunidad de Madrid (European Structural and Investment Funds) to VdL. This protocol was adapted from DuranteRodríguez et al. (2018) for the method to design and construct a post-translational metabolic switch driven to decoupling the bacterial growth from biopolymer production in E. coli.

\section{Competing interests}

The authors declare no conflicts of interest.

\section{References}

1. Avcilar-Kucukgoze, I., and Ignatova, Z. (2017). Rewiring host activities for synthetic circuit production: a translation view. Biotechnol Lett 39(1): 25-31.

2. Calles, B., Goñi-Moreno, A. and de Lorenzo, V. (2019). Digitalizing heterologous gene expression in Gram-negative bacteria with a portable ON/OFF module. Mol Syst Biol 15(12): e8777.

3. Doma, M. K. and Parker, R. (2007). RNA quality control in eukaryotes. Cell 131(4): 660-668.

4. Durante-Rodríguez, G., de Lorenzo, V. and Nikel, P. I. (2018). A post-translational metabolic switch enables complete decoupling of bacterial growth from biopolymer production in engineered Escherichia coli. ACS Synth Biol 7(11): 2686-2697. 
5. Durfee, T., Nelson, R., Baldwin, S., Plunkett, G., 3rd, Burland, V., Mau, B., Petrosino, J. F., Qin, X., Muzny, D. M., Ayele, M., Gibbs, R. A., Csörgő, B., Pósfai, G., Weinstock, G. M. and Blattner, F. R. (2008). The complete genome sequence of Escherichia coli DH10B: insights into the biology of a laboratory workhorse. J Bacteriol 190(7): 2597-2606.

6. Guzmán, L. M., Belin, D., Carson, M. J. and Beckwith, J. (1995). Tight regulation, modulation, and high-level expression by vectors containing the arabinose PBAD promoter. $J$ Bacteriol 177(14): 4121-4130.

7. Isaacs, F. J., Dwyer, D. J., Ding, C., Pervouchine, D. D., Cantor, C. R. and Collins, J. J. (2004). Engineered riboregulators enable post-transcriptional control of gene expression. Nat Biotechnol 22(7): 841-847.

8. Lou, C., Stanton, B., Chen, Y. J., Munsky, B. and Voigt, C. A. (2012). Ribozyme-based insulator parts buffer synthetic circuits from genetic context. Nat Biotechnol 30(11): 1137-1142.

9. Lutz, R. and Bujard, H. (1997). Independent and tight regulation of transcriptional units in Escherichia coli via the LacR/O, the TetR/O and AraC//1-l 2 regulatory elements. Nucleic Acids Res 25(6): 1203-1210.

10. Sambrook, J. and Russell, D. W. (2001). Molecular cloning: a laboratory manual. Cold Spring Harbor Laboratory, Cold Spring Harbor, NY, USA.

11. Shoemaker, C. J., Eyler, D. E. and Green, R. (2010). Dom34:Hbs1 promotes subunit dissociation and peptidyl-tRNA drop-off to initiate no-go decay. Science 330(6002): 369-372.

12. Silva-Rocha, R., Martinez-Garcia, E., Calles, B., Chavarría, M., Arce-Rodríguez, A., de Las Heras, A., Páez-Espino, A. D., Durante-Rodríguez, G., Kim, J., Nikel, P. I., Platero, R. and de Lorenzo, V. (2013). Nucleic Acids Research. 41(Database issue): D666-675.

13. Stevens, R. C. (2000). Design of high-throughput methods of protein production for structural biology. Structure 8(9): R177-185.

14. Verchot, J., Koonin, E. V. and Carrington, J. C. (1991). The 35-kDa protein from the N-terminus of the potyviral polyprotein functions as a third virus-encoded proteinase. Virology 185(2): 527535.

15. Volke, D. C., Turlin, J., Mol, V. and Nikel, P. I. (2020). Physical decoupling of XyIS/Pm regulatory elements and conditional proteolysis enable precise control of gene expression in Pseudomonas putida. Microb Biotechnol 13(1): 222-232.

16. Wu, G., Yan, Q., Jones, J. A., Tang, Y. J., Fong, S. S., and Koffas, M. A. G. (2016). Metabolic burden: cornerstones in synthetic biology and metabolic engineering applications. Trends Biotechnol 34(8): 652-664. 